\title{
The Authorized Economic Operator in the Pacific Alliance
}

\author{
Jorge Vega Cancino \\ Institute of International Studies \\ University of Chile \\ jorgevegacancino@gmail.com
}

This paper portrays an up-to-date status of the Authorized Economic Operator (AEO) Programs in the Pacific Alliance (PA), shining a light on the different obstacles these programs have encountered and what their probable outcomes will be in the coming years. The main goal with this investigation is to answer two questions: (1) What is the current situation of the AEO programs within the Pacific Alliance? (2) What impact will the PA's AEO programs have in the medium term? Can these programs become as successful as the Customs-Trade Partnership Against Terrorism (C-TPAT)?

Research for this paper was funded by the Swiss State Secretariat for Economic Affairs under the SECO / WTI Academic Cooperation Project, based at the World Trade Institute of the University of Bern, Switzerland.

SECO working papers are preliminary documents posted on the WTI website ( $\underline{w w w . w t i . o r g}$ ) and widely circulated to stimulate discussion and critical comment. These papers have not been formally edited. Citations should refer to a "SECO / WTI Academic Cooperation Project" paper with appropriate reference made to the author(s). 


\title{
THE AUTHORIZED ECONOMIC OPERATOR IN THE PACIFIC ALLIANCE
}

\author{
SECO/WTI ACADEMIC COOPERATION PROJECT \\ WORKING PAPER
}

Jorge Vega Cancino. ${ }^{1}$

\begin{abstract}
The Pacific Alliance (PA) is a regional integration initiative comprised of Chile, Colombia, Mexico, and Peru. With 215 million inhabitants, the PA's countries account for just over $40 \%$ of Latin American GDP, as well as 52\% of total trade and $45 \%$ of FDI in the region. They are also the four nations that occupy the top four places for Latin America in the 2016 World Bank's Doing Business index.As a block, theyaspire to becoming a platform for political articulation and projection to the world, with an emphasis on the Asia-Pacific region. Indeed, an example of these common objectives is the Authorized Economic Operator (AEO), an institution born after the establishment of the Customs-Trade Partnership Against Terrorism (C-TPAT) by the U.S. Customs and Border Protection (CBP), as a part of a multi-layered cargo enforcement strategy. Through this program, the CBP works with the trade community to strengthen international supply chains and improve border security.

The AEO Program is, at the same time, part of a much larger and ambitious global initiative, supported by both the World Trade Organization (WTO) and the World Customs Organization(WCO). Each of these international institutions have encouraged new measures towards Trade Facilitation, where the SAFE Framework is a specific application of the principles set by the Bali Package.

The AEO Program is aimed at cooperation based on 3 pillars: (1) Customs-toCustoms; (2) Customs-to-Business and Authorized Economic Operator; and (3) Cooperation between Customs and other Government and Inter-Government agencies.

This research portrays an up-to-date status of the AEO Programs in the PA, while shining a light on the different obstacles these programs have encountered and what probable outcomes will be in the coming years.

Our main goal with this investigation is to answer two questions:

1. What is the current situation of the AEO programs within the Pacific Alliance?

2. What impact will the PA's AEO programs have in the medium term? Can these programs become as successful as C-TPAT?
\end{abstract}

\footnotetext{
${ }^{1}$ Lawyer, Master in International Relations, Pontifical University of Valparaíso.
} 


\section{Introduction: The AEO and its Role in International Trade.}

A main focus for the WTO has been to achieve the simplification, modernization and harmonization of export and import processes, an objective summarized under the concept of 'Trade Facilitation'. Therefore, on the WTO's 2013 Ministerial Conference in Bali, on the landmark Trade Facilitation Agreement (TFA), an international instrument was concluded by its members, and entered into force on 22 February 2017, following its ratification by two-thirds of the WTO membership. The TFA contains provisions for expediting the movement, release and clearance of goods, including goods in transit. It also sets out measures for effective cooperation between customs and other appropriate authorities on trade facilitation and customs compliance issues. It further contains provisions for technical assistance and capacity building in this area. ${ }^{2}$

Although it is an independent initiative, started in 2005, the WCO's SAFE Framework is on the same track as the TFA. Accordingly, the WCO pledged to aid in the implementation of the 'Bali Package'. Although concurring, the SAFE Framework offers its own specific scope, on how Customs administrations must work cooperatively -among themselves and with the private sector as well- in order to achieve objectives common to both the WTO and the WCO. The AEO is a very relevant aspect of these measures.

In order to establish the concept framework for our study, we need to first assess what the AEO entails. For this purpose, it is necessary to analyze its peculiarities, pursuant to the $5^{\text {th }}$ version of the SAFE Framework (the latest one), which was released by the WCO in June, 2015. This document defines the AEO as a party involved in the international movement of goods in whatever function that has been approved by or on behalf of a national Customs administration, in compliance with WCO or equivalent supply chain security standards. AEOs may include manufacturers, importers, exporters, brokers, carriers, consolidators, intermediaries, ports, airports, terminal operators, integrated operators, warehouses, distributors and freight forwarders. ${ }^{3}$

Since the end-to-end management of goods moving across borders became the standard in international trade, the AEO arose as an institution with a double purpose: on the one hand, it helps to add security to the supply chain; on the other, it reaps commercial benefits, such as faster processing of goods through Customs, e.g. via reduced examination rates. This, in turn, translates into savings in time and costs, as it also reduces multiple and complex reporting requirements. These processes will ensure that AEOs see a benefit to their investment in good security systems and practices, including reduced risk-targeting assessments and inspections. ${ }^{4}$ AEOs that meet the criteria specified by Customs should reasonably expect to participate in simplified and rapid release procedures on the provision of minimum information. ${ }^{5}$ Benefits also include improved security levels and an enhanced reputation for the organization,

\footnotetext{
${ }^{2}$ WTO Official Website, Trade Topics, Trade Facilitation, https://www.wto.org (Visited in January, 2017).

${ }^{3}$ WCO, SAFE Framework 2015, p. I/1, available on http://www.wcoomd.org (visited in February, 2017).

${ }^{4}$ WCO, SAFE Framework 2015, p. 5, available on http://www.wcoomd.org (visited in February, 2017).

${ }^{5}$ WCO, SAFE Framework 2015, p. 12, available on http://www.wcoomd.org (visited in February, 2017).
} 
increased business opportunities, improved understanding of Customs requirements, and better communication between the AEO and the Customs administration. ${ }^{6}$

\section{Strengthening Customs - Business co-operation is a main pillar and objective of} the SAFE Framework; accordingly, it has thoroughly established the requirements to become an AEO. To convey a broad look at this institution, we will summarize its core aspects below:

\section{Table 1: AEO Conditions, Requirements and Benefits. ${ }^{7}$}

1. Demonstrated Compliance with Customs Requirements: Customs shall take into account the demonstrated compliance history of a prospective AEO when considering the request for AEO status.

2. Satisfactory System for Management of Commercial Records: The AEO shall maintain timely, accurate, complete and verifiable records relating to import and export. Maintenance of verifiable commercial records is an essential element in the security of the international trade supply chain.

3. Financial Viability: Financial viability of the AEO is an important indicator of an ability to maintain and improve upon measures to secure the supply chain.

4. Consultation, Co-operation and Communication: Customs, other competent authorities and the AEO, at all levels, international, national and local, should consult regularly on matters of mutual interest, including supply chain security and facilitation measures, in a manner which will not jeopardize enforcement activities. The results of this consultation should contribute to Customs development and maintenance of its risk management strategy.

5. Education, Training and Awareness: Customs and AEOs shall develop mechanisms for the education and training of personnel regarding security policies, recognition of deviations from those policies and understanding what actions must be taken in response to security lapses.

6. Information Exchange, Access and Confidentiality: Customs and AEOs, as part of an overall comprehensive strategy to secure sensitive information, shall develop or enhance the means by which entrusted information is protected against misuse and unauthorized alteration.

7. Cargo Security: Customs and AEOs shall establish and/or bolster measures to ensure that the integrity of cargo is maintained and that access controls are at the highest appropriate level, as well as establishing routine procedures that contribute to the security of cargo.

8. Conveyance Security: Customs and AEOs shall jointly work toward the establishment of effective control regimes, where not already provided for by other national or international regulatory mandate, to ensure that transport conveyances are capable of being effectively secured and maintained.

9. Premises Security: Customs, after taking into account the views of AEOs and their necessary compliance with mandatory international standards, shall establish the requirements for the implementation of meaningful Customsspecific security enhancement protocols that secure buildings, as well as ensure the monitoring and controlling of exterior and interior perimeters.

10. Personnel Security: Customs and AEOs shall, based on their authorities and competencies, screen the background of prospective employees to the extent legally possible. In addition, they shall prohibit unauthorized access to facilities, transport conveyances, loading docks and cargo areas that may reasonably affect the security of those areas in the supply chain under their responsibility.

11. Trading Partner Security: Customs shall establish AEO requirements and mechanisms whereby the security of the global supply chain can be bolstered through the commitment of trading partners to voluntarily increase their security measures.

12. Crisis Management and Incident Recovery: In order to minimize the impact of a disaster or terrorist incident, crisis management and recovery procedures should include advance planning and establishment of processes to operate in such extraordinary circumstances.

13. Measurement, Analyses and Improvement: The AEO and Customs should plan and implement monitoring, measurement, analysis and improvement processes in order to :

- assess consistency with these guidelines;

- ensure integrity and adequacy of the security management system;

- identify potential areas for improving the security management system in order to enhance supply chain security. Source: WCO SAFE Framework 2015.

As established above, this framework sets forth the criteria by which businesses in the supply chain can obtain authorized status as a security partner. It addresses issues such as threat assessment, a security plan adapted to those threats, a communication

\footnotetext{
${ }^{6}$ WCO, SAFE Framework 2015, p. 24, available on http://www.wcoomd.org (visited in February, 2017).

${ }^{7}$ WCO, SAFE Framework 2015, p. IV/3 - IV/14, available on http://www.wcoomd.org (visited in February, 2017).
} 
plan, procedural measures to prevent irregular or undocumented goods entering the international supply chain, physical security of buildings and premises used as loading or warehousing sites, security of cargo, means of transport, personnel vetting, and protection of information systems. ${ }^{8}$ All of these requirements fall under the 'Authorized Supply Chain' concept, where all participants in an international trade transaction are approved by Customs by means of observing specified standards in the secure handling of goods and relevant information. Consignments passing from origin to destination entirely within such a chain would benefit from an integrated cross-border simplified procedure, where only one simplified declaration with minimum information would be required for both export and import purposes. ${ }^{9}$

In sum, the key aspect here is in the collaboration established on both national and international levels: private and public sectors within the country cooperate to create a secure supply chain; while countries and their respective public agencies set forth the rules and objectives. These goals range from preventing terrorism, to enabling faster physical trade of goods among nations. For example, one of the main focal points, security, is provided for within AEO measures in the sense of ensuring the safekeeping of buildings, monitoring and controlling exterior and interior perimeters, access points that prohibit unauthorized entering of facilities, conveyances, loading docks and cargo areas. Access control of facilities in the secure supply chain incorporates managerial control over the issuance and adequate control of identification badges (employee, visitor, vendor, etc.) and other access devices, including keys, access cards, and other devices that allow for unfettered access to company property and assets. ${ }^{10}$

Considering international cooperation as one of the foundations of WCO efforts, agreements between countries are essential. Consequently, the SAFE Framework also aims at 'Mutual Recognition'; a broad concept whereby an action or decision taken or an authorization that has been properly granted by one Customs administration, is recognized and accepted by another Customs administration. The standardized approach to AEO authorization provides a solid platform for the long-term development of international systems of mutual recognition of AEO status at bilateral, sub-regional, regional and, perhaps in the near future, global level. In order for a system of mutual recognition to work it is essential that: ${ }^{11}$

1. The AEO programs are compatible and conform to the standards and principles set out in the SAFE Framework;

2. An agreed-upon set of common standards that include sufficiently robust "action" provisions for both Customs and AEOs, have been established;

3. Standards are applied in a uniform manner so that one Customs administration may have confidence in the authorization of another;

\footnotetext{
${ }^{8}$ WCO, SAFE Framework 2015, p. 24, available on http://www.wcoomd.org (visited in February, 2017).

${ }^{9}$ WCO, SAFE Framework 2015, p. 12, available on http://www.wcoomd.org (visited in February, 2017).

${ }^{10}$ WCO, SAFE Framework 2015, p. 26, available on http://www.wcoomd.org (visited in February, 2017).

${ }^{11}$ WCO, SAFE Framework 2015, p. 36, available on http://www.wcoomd.org (visited in February, 2017).
} 
4. If the certification process is delegated to a designated authority by an authorizing Customs administration, there shall be an agreed upon mechanism and standards for that authority;

5. Legislation enabling the implementation of a mutual recognition system is in place.

While the SAFE Framework is considered a minimum set of standards, it will be implemented at various stages in accordance with each administration's capacity ("phased approach") and the necessary legislative authority. ${ }^{12}$ This affirmation is very relevant when we think of the Pacific Alliance and its various states of development, especially regarding the AEO programs, as we will learn briefly.

\section{A Brief Look at the C-TPAT Experience. ${ }^{13}$}

C-TPAT is a voluntary program. It began in November 2001, whereas the Security and Accountability For Every Port Act (SAFE Port Act) of 2006 provided a statutory framework and imposed strict oversight requirements. When companies join the partnership, they sign an agreement to work with CBP to protect the supply chain, identify security gaps and implement specific security measures and best practices. Additionally, partners provide CBP with a security profile outlining the specific security measures the company has in place. Applicants must address a broad range of security topics and present security profiles that list action plans to align security throughout their supply chain. C-TPAT members are considered low-risk and are therefore less likely to be examined. This designation is based on a company's past compliance history, security profile, and the validation of a sample international supply chain.

By extending the United States' zone of security to the point of origin, the customs-trade partnership allows for better risk assessment and targeting, freeing U.S. Customs and Border Protection (CBP) to allocate inspectional resources to more questionable shipments. Companies must be eligible and agree to comply with the CTPAT Security Criteria. In return CBP provides incentives and benefits like expedited processing. Today, there are more than 11.325 certified companies. These companies account for over 54 percent (by value) of what is imported into the United States. Below is a breakdown of the 11.325 C-TPAT Certified companies: ${ }^{14}$

$\begin{array}{ll}\text { U.S. Importers } & 4.246 \\ \text { U.S. Exporters } & 492 \\ \text { U.S. Customs Brokers } & 867 \\ \text { Consolidators/3PLs } & 984 \\ \text { Carriers (Airlines, Sea Carriers, Cross Border Trucking Companies) } & 3.153 \\ \text { Canadian \& Mexican Manufacturers } & 1.518 \\ \text { Marine Port Terminal Operators } & 65\end{array}$

\footnotetext{
${ }^{12}$ WCO, SAFE Framework 2015, p. 3, available on http://www.wcoomd.org (visited in February, 2017).

${ }^{13}$ Sources: http://www.c-tpat.com ; http://www.cbp.gov; http://www.miq.com

${ }^{14}$ Source: http://c-tpat.com/what-is-ctpat/ (visited in March, 2017).
} 
Table 2: List of C-TPAT Benefits. ${ }^{15}$

1. Reduction in U.S. Customs Inspections: When cargo is imported, CBP assigns an undisclosed risk value to each shipment; assessing such risk factors as: country of origin, supplier, type of product, developed intelligence.

When a C-TPAT certified company imports cargo, CBP deducts points from the risk value. This results in the imported cargo being placed in a preferred category. Even if the shipment is selected to be inspected, the process is faster if the shipment is being imported by a C-TPAT certified U.S. importer.

All of this translates into reduced inspection fees, customs fees, cargo fees, increased speed to market and an immediate positive effect on a company's bottom line.

Entries filed by Tier II C-TPAT certified U.S. importers are 3.5 times less likely to be selected for a security based examination whereas Tier III C-TPAT certified U.S. importers are 9 times less likely to be selected.

2. Front of the Line Privileges: Granted to full C-TPAT containers/trailers that are selected for an examination.

To the extent possible and practicable the containers/trailers can be moved ahead of any non C-TPAT containers/trailers awaiting exam, regardless of how long they have been there. Containers/trailers will not wait as long in line at a Container Examination Site.

Overall: Reduction in time and cost of getting cargo released by U.S. Customs

3. Priority Access: In the event of a national emergency or terrorist act, which results in the closing of an airport, land or sea port of Entry; C-TPAT certified shipments will have priority access into the U.S. once the U.S. Port of Entry reopens.

4. Free and Secure Trade (FAST) Lanes: Expedited clearance across the borders between the U.S. \& Canada / U.S. \& Mexico via dedicated FAST lanes.

5. Additional Benefits: (1) Maintain business relationship with an existing customer that is requiring your Company to be certified. (2) Obtain new customers. (3) Increase competitiveness. (4) Minimize the probability of a disruption to your supply chain. (5) Improve predictability in importing cargo from abroad or transporting cargo to the U.S.

Source: C-TPAT Official Website.

Below is a diagram of every point where the Supply Chain is susceptible to breach. Thus, C-TPAT aims at collaborative results, encouraging every link to upgrade its security standards:

- Diagram of Supply Chain Opportunities to Insert Contraband/Weapons of Mass Effect:

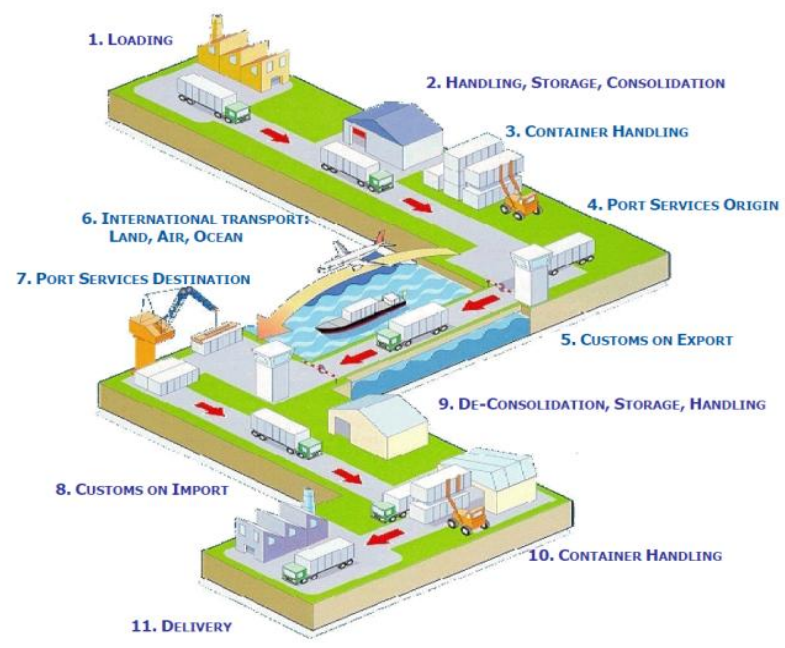

Source:http://www.miq.com

\footnotetext{
${ }^{15}$ Source: http://c-tpat.com/what-is-ctpat/c-tpat-benefits/ (visited in March, 2017).
} 


\section{The AEO in the Pacific Alliance.}

With 215 million inhabitants, the Pacific Alliance countries account for just over $40 \%$ of Latin American GDP, as well as $52 \%$ of total trade and $45 \%$ of FDI in the region. They are also the four nations that occupy the top four places for Latin America in the 2016 ranking of the World Bank 'Doing Business' index, which estimates the ease of doing business in the countries. ${ }^{16}$ As of 2015, the PA's main port's container traffic adds up to a very relevant total of 9.343.198 TEUs (see table below), which considered as a whole, positions it within the top 20 ports in the world. ${ }^{17}$

\begin{tabular}{|l|l|r|r|}
\hline \multicolumn{1}{|c|}{ Table 3: PA's PORT TRAFFIC 2015 (ECLAC FIGURES) ${ }^{18}$} \\
\hline \multicolumn{1}{|c|}{ Country } & \multicolumn{1}{|c|}{$\begin{array}{c}\text { Place Port Ranking } \\
\text { ECLAC 2015 }\end{array}$} & $\begin{array}{r}\text { Volume } \\
\text { in TEU }\end{array}$ \\
\hline Manzanillo & Mexico & 5 & 2458135 \\
\hline Callao & Peru & 6 & 1900444 \\
\hline San Antonio & Chile & 12 & 1170184 \\
\hline Lázaro Cárdenas & Mexico & 14 & 1068747 \\
\hline Veracruz & Mexico & 15 & 931613 \\
\hline Buenaventura & Colombia & 16 & 911533 \\
\hline Valparaíso & Chile & 17 & \\
\hline & & Total & \\
\hline
\end{tabular}

Taking these figures into consideration, it is a relevant matter when we think of the AEO as a part of an economic agreement that allows for a faster and more secure movement of goods. At the same time, it upgrades the standards so it helps to build a reliable reputation within its partners in the developed world. This is a stand out example of both South - South cooperation and of a multilateral approach at international economic relations.

In regards to the legal status of the AEO, last year saw the Additional Protocol to the PA's Framework Agreement enter into force. Within its provisions, Chapter V Article 5.8 is dedicated to the Authorized Economic Operator: ${ }^{19}$

'1. The customs administrations of the Parties shall promote the strengthening of the Authorized Economic Operator programs (hereinafter referred to as 'AEO'), in accordance with the WCO Framework of Standards to Secure and Facilitate Global Trade (hereinafter referred to as the 'SAFE Framework').

2. The customs administrations of the Parties shall encourage and work in Mutual recognition agreements (hereinafter referred to 'MRA') of the Parties' AEO programs.'

Periodical meetings have been held by the PA's Technical Group (more specifically its Trade Facilitation and Customs Cooperation subgroup). In these

\footnotetext{
${ }^{16}$ Source: http://www.bbc.com/mundo/noticias-36709925 (visited in March, 2017), translated by the author.

${ }^{17}$ See the Top 50 World Container Ports http://www.worldshipping.org/about-the-industry/globaltrade/top-50-world-container-ports (visited in March, 2017).

${ }^{18}$ ECLAC Official website

http://www.cepal.org/sites/default/files/infographic/files/cepal_ranking_puertos_esp-okweb.pdf (visited in March, 2017).

${ }^{19}$ Additional Protocol to the Pacific Alliance's Frame Agreement, Translated by the author.
} 
reunions, according to Chile's AEO Program Director, Jorge Yany, countries share valuable info, set forth common goals and receive help from C-TPAT experts. They are currently looking forward to the establishment of AEO Programs in all four PA's countries. PA members do not have the same level of development in these programs; indeed, Chile has the most work left to be done. ${ }^{20}$ Nevertheless, firm steps are being taken towards a PA MRA, as the Customs administrations of all four PA countries signed an action plan to negotiate a multilateral agreement for the recognition of their AEO Programs. The signature took place at the 3rd AEO Global Conference held from May 11 to $13^{\text {th }}, 2016$, in Cancun, Mexico. ${ }^{21}$

Table 4: Pacific Alliance / USA Customs Country Profile (WCO Annual Report 2015). ${ }^{22}$

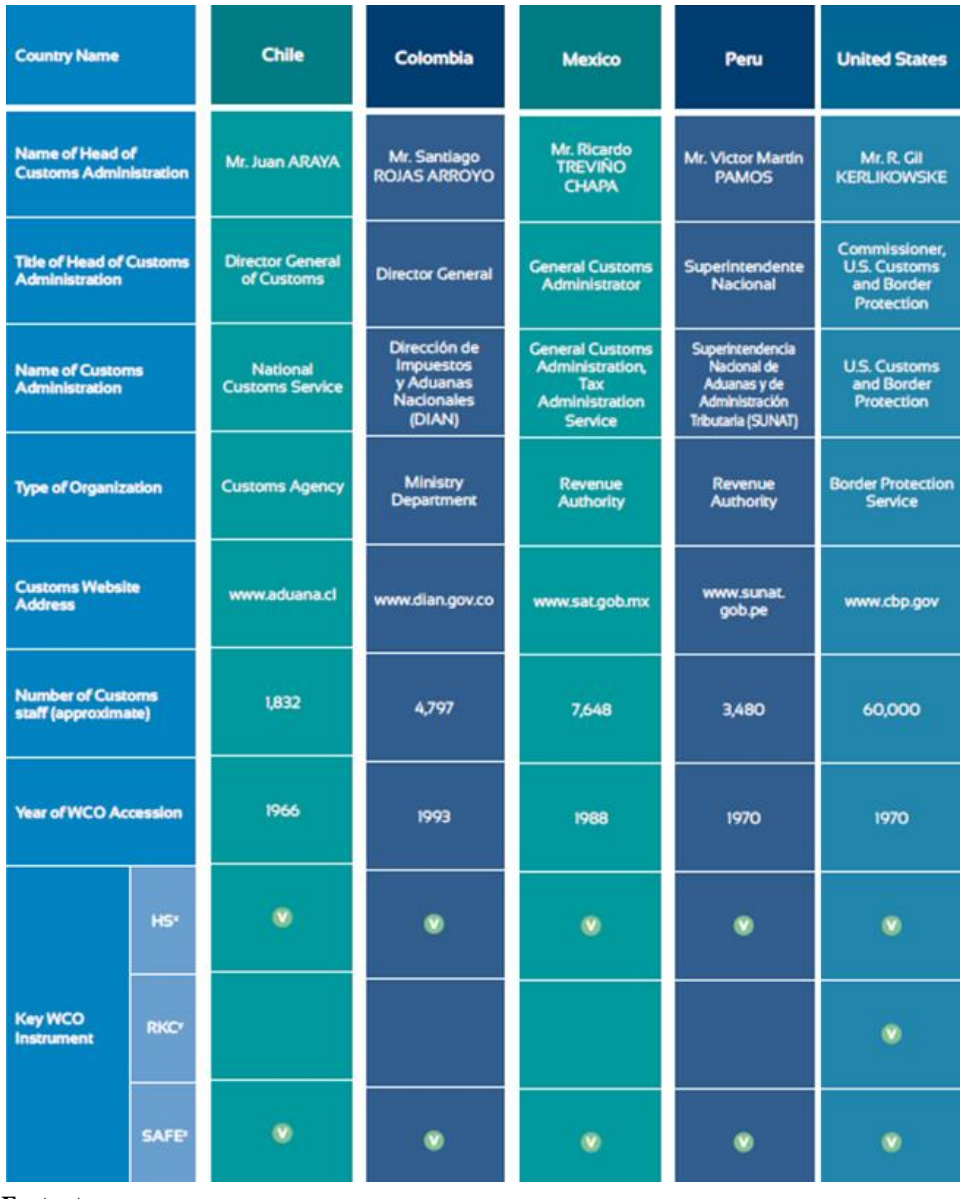

Footnotes

HS Harmonized Commodity Description and Coding System

RKC Revised Kyoto Convention

SAFE Framework of Standards to Secure and Facilitate Global Trade

Explanatory Notes

Type of Organization: 'Ministry Department' indicates that the Customs administration is a department, bureau, or division within a Ministry, such as the Ministry of Finance or the Ministry of the Interior. 'Customs Agency' indicates that the Customs administration is an autonomous Ministry or committee, or an independent agency, even if affiliated to a Ministry. 'Revenue Authority' indicates that the Customs administration is a pillar of an agency in which Customs and Tax authorities are integrated. 'Border Protection Service' indicates that the Customs administration is responsible for immigration services, such as visa verification at borders, in addition to the Customs portfolio.

\footnotetext{
${ }^{20}$ Interview held between Mr. Yany and the author on December, 2016.

${ }^{21}$ Source: Inter - American Development Bank Official Website

http://www.iadb.org/en/topics/trade/customs-of-the-pacific-alliance-countries,20247.html (visited in April, 2017).

${ }^{22}$ WCO Annual Report 2015-2016, p. 24 - 53. Available on http://www.wcoomd.org (visited in February, 2017).
} 

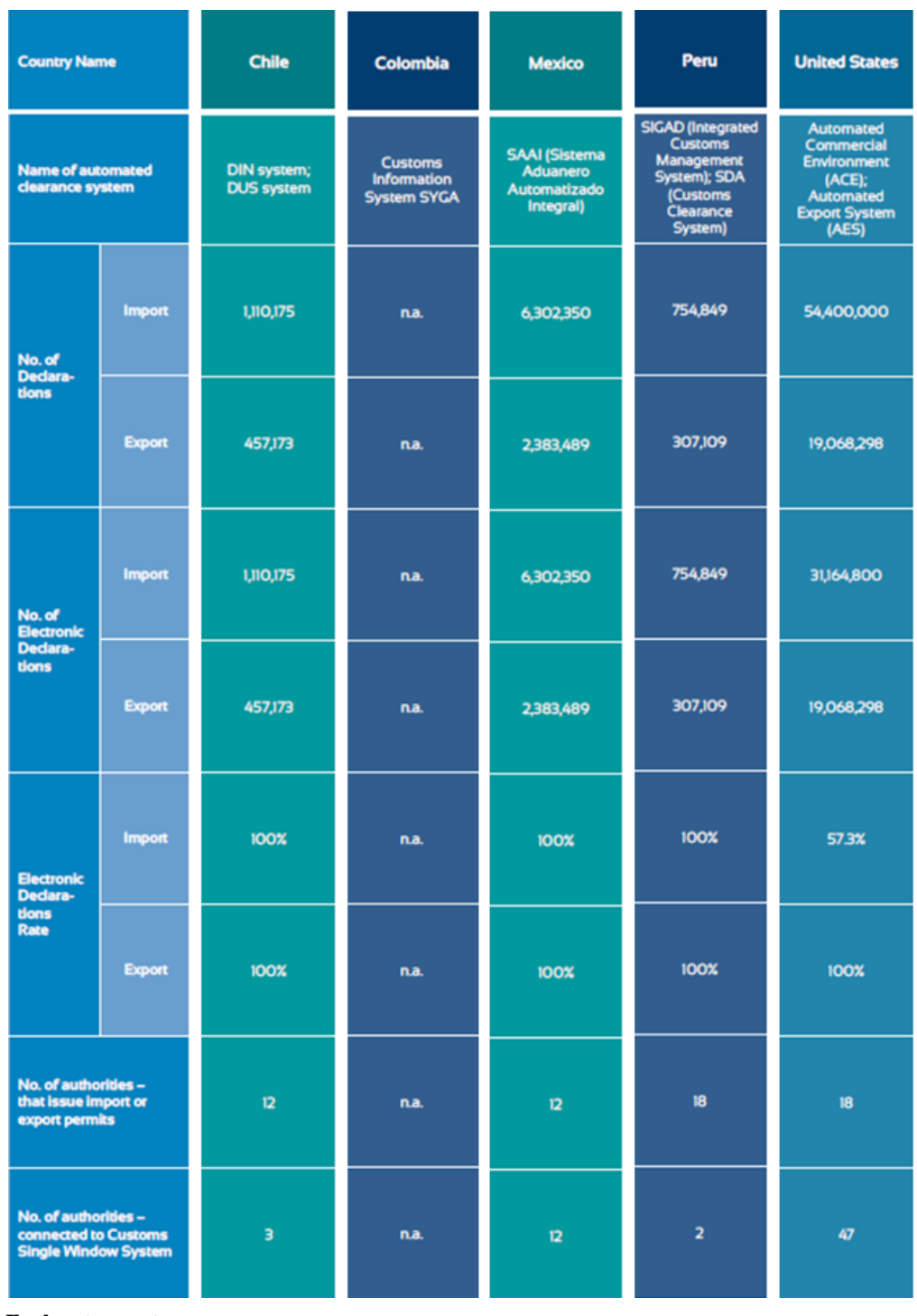

Explanatory notes

The 'Number of Declarations' includes all paper-based and electronic declarations processed by a Customs administration throughout the year 2015. The 'Electronic Declarations Rate'was calculated by dividing the 'Number of Electronic Declarations' by the 'Number of Declarations'.

In the Customs country profile shown above (info taken from the WCO AEO Compendium $2016^{23}$ ), an idea of the volume of declarations these agencies manage and of their workforce as well, emerges. This data was included so that the reader could have a whole picture of the reality of the PA's Customs Administrations. This, just before the analysis of each PA member and their current AEO Program's status.

For each country, the paper will show a table that summarizes all the information related to the country's AEO Program, also taken from the WCO AEO Compendium 2016, and an up-to-date status of the program, complemented with information taken from various other sources.

\footnotetext{
${ }^{23}$ Available at http://www.wcoomd.org (visited in February, 2017).
} 


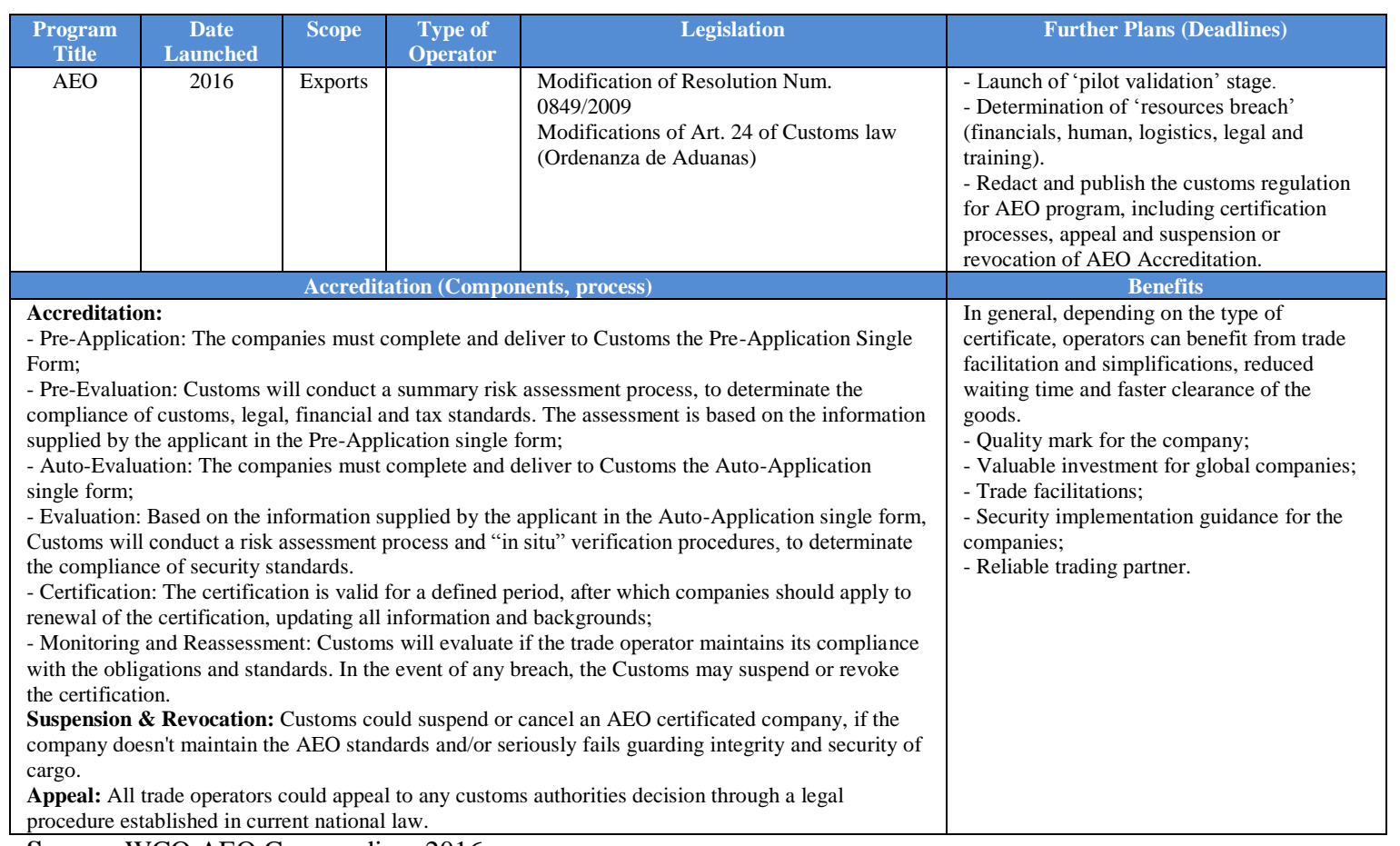

Source: WCO AEO Compendium 2016.

On March 13" , 2017, Chile passed the law number 20997, of "Customs Modernization". Its article 23 bis creates the AEO's legal basis, allowing for the Head of the Customs Administration to implement a regulation and approve AEO status for those operators that comply with the requirements. This development speaks volumes about the current status of the Chilean AEO program, where only pilot programs have been implemented. The country still awaits the Ministry of Treasury to dictate a bylaw that will thoroughly regulate the AEO. However, this should take place very soon; in the interview with Jorge Yany on October, 2016, it was stated that this new regulation was already in the making and that the Chilean Customs is working on the implementation stage of the Program, which will initially be available for customs brokers and exporters.

Based on their accumulated experience from the pilot programs, a new campaign was started to rebuild trust in the AEO Program, with a 3 year work plan, aimed at 3 different lines of development:

1- The Private Sector, centering on preparing companies for the certification;

2- Within the Customs Service, to train the workforce for the new challenges, creating an institutional basis;

3- International cooperation, using the $\mathrm{WCO}$ and the PA as platforms.

Chile's efforts, according to Mr. Yany, aspire to emulate other successful experiences -such as C-TPAT-, and to thus create a Program that will grow deep roots within the Chilean Foreign Trade community. Although they aim high, the protracted attempts have many explanations; the pilot programs date from as far as 2008, and after 
9 years in the making, he tells us that there have been both internal and external factors in accounting for the delay:

- Internal or Structural Factor: Customs are used to being inspectors; they control the flow of goods. The AEO requires letting go of some of these inspections, based on risk assessment. This is resisted by some within Customs, as they have apprehension for new institutions and their possible results. It requires establishing a new paradigm.

- External Factor: Corporations must be convinced of the real benefits associated with the AEO Program, convincing them of the actual gain they can get from perfecting their security standards.

- Legal Factor: Updating regulations to the 2015 SAFE Framework requires modernization and coordination between public services inside the country. Certification must be valid for every public service involved in the international trade of goods.

\section{b) Colombia.}

\begin{tabular}{|c|c|c|c|c|c|c|}
\hline $\begin{array}{c}\text { Program } \\
\text { Title }\end{array}$ & $\begin{array}{c}\text { Date } \\
\text { Launched }\end{array}$ & Scope & $\begin{array}{l}\text { Type of } \\
\text { Operator }\end{array}$ & $\begin{array}{l}\text { No. of } \\
\text { Operators }\end{array}$ & Legislation & Further Plans (Deadlines) \\
\hline \multicolumn{4}{|c|}{ Accreditation (Components, process) } & \multicolumn{3}{|c|}{ Benefits } \\
\hline \multicolumn{4}{|c|}{$\begin{array}{l}\text { Categories: } \\
\text { - Safety and Simplification. } \\
\text { - Safety and Sanitary simplification. }\end{array}$} & \multicolumn{3}{|c|}{$\begin{array}{l}\text { - Recognition as safe and reliable operators in the supply chain by control authorities. } \\
\text { - Assign an operations officer from each authority that will support its operations. } \\
\text { - Participation in AEO Congress. } \\
\text { - Participation in training activities scheduled for AEO, by the supervisory authorities in matters } \\
\text { within its competence. } \\
\text { - Decreased number of awards, physical inspections and documentary operations for export, } \\
\text { import and customs transit by the Tax and Customs and decreased physical inspections for export } \\
\text { operations by the Narcotics Division National police. } \\
\text { - Using special simplified procedures for the development of measures of recognition or } \\
\text { inspection, as the case when these are identified as a result of risk analysis systems by the } \\
\text { supervisory authorities. } \\
\text { - Using channels and special mechanisms for conducting foreign trade operations that are filled } \\
\text { suede Control Authorities. } \\
\text { - Direct action of exporters and importers as respondents to the Tax and Customs regimes import, } \\
\text { export and transit. } \\
\text { - Recognition of goods under the terms stated in the customs legislation, for exporters and } \\
\text { importers when acting as witnesses, and so require. } \\
\text { - Tax benefits. }\end{array}$} \\
\hline
\end{tabular}

Source: WCO AEO Compendium 2016.

Although data shown above is very recent, Miss Luz Murcia, AEO Coordinator for DIAN, was contacted directly. She answered via email giving the following insight on their program: ${ }^{24}$ Currently, Colombia has 23 companies authorized as AEO Exporters. The Program is available to exporters and importers, and works among institutions, whereas there are several control authorities that have security requirements and grant benefits:

- For exporters: Customs, Anti-narcotics Police, Colombian Agricultural Institute, National Institute for Drug and Food Surveillance.

- For importers: Customs, Anti-narcotics Police and the Colombian Agricultural Institute.

\footnotetext{
${ }^{24}$ Interview Via Email, email with answers received in January 6, 2017, from Luz Murcia Reyes, AEO Coordinator for Colombia's DIAN.
} 
In the area of Mutual Recognition Agreements, they are currently in the implementation phase of the action plan, for a multilateral MRA of the AEO program with Pacific Alliance Customs. Future expectations are to continue the development of the Program by incorporating new links in the international supply chain.

To the question about which setbacks are acting as deterrents, she said that they still need to offer more attractive benefits to businesses. Also, they have work to be done in developing the program with their inter-institutional model, since continuing that development requires the approval of different issues (e.g., regulations) by all participating control authorities.

When speaking about their inspiring models, she confirmed that C-TPAT and European AEO's are the examples they have followed, always within the provisions of the SAFE Framework. Finally, regarding the PA's joint work and the future of the program, she said -as already stated in this study- that there is a regional strategy for the development and strengthening of the AEO program in the region, consisting of the exchange of best practices and frequent contact, both present and virtual. The AEO in Colombia, with the issuance of the new customs regulation decree 390 of 2016 (Article 34), has consolidated itself as a user with the full confidence of Colombian Customs and, because of this, any AEO in Colombia, will have access to multiple benefits in terms of Facilitation, which should see a significant increase in the demand for the Program, and a consequent increase in the number of companies that are authorized as AEO's. Furthermore, with the signing of the MRA, interesting benefits are expected in terms of facilitating trade with foreign Customs, which will be reflected in an increase in the competitiveness of Colombian exports.

\section{c) Peru.}

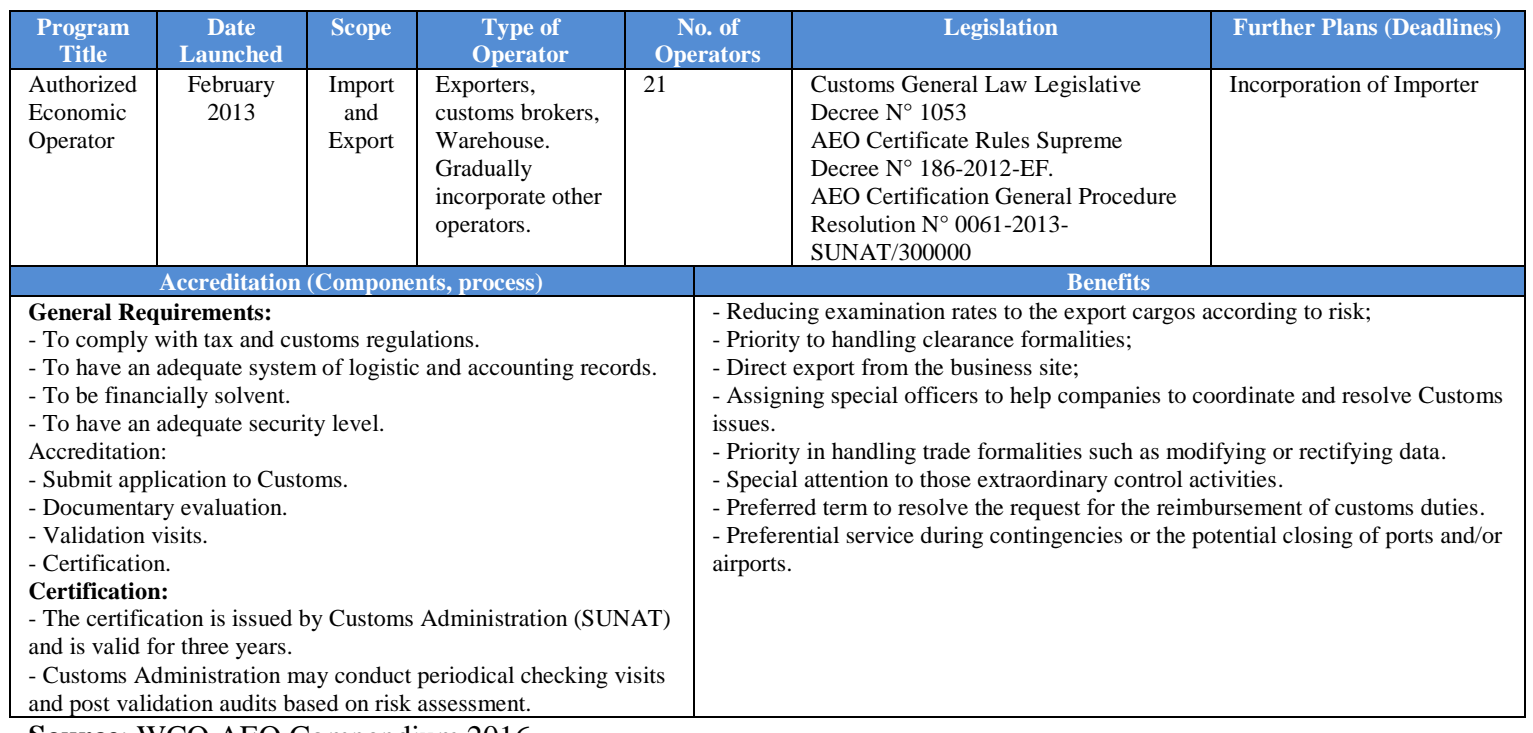

Source: WCO AEO Compendium 2016. 
According to the Peruvian Customs Authority (SUNAT) official website, to date there are 49 AEO's in Peru: 21 exporters, 23 customs brokers, 4 warehouses and 1 importer. ${ }^{25}$ Although it more than doubles Colombia's numbers, it is still a very small number of operators. When we look at the reasons for slow growth of the program, considering its 4 years of lifespan; they are very similar to those of Colombia; better regulations and more benefits for AEO's are needed. Another focal point is increasing the promotion of the program, so more eligible candidates get acquainted with it. ${ }^{26}$ In light of this, last year, SUNAT eliminated the minimum annual export amount (US \$ 3.5 million) to be accredited as an AEO, allowing for small and medium-sized enterprises to obtain certification. AEO's exported more than US $\$ 1.536$ million in 2016; if Peruvian total exports for 2016 were valued at US \$ 25 billion, AEO's represented $6,14 \%$ of the total. ${ }^{27}$

d) Mexico.

\begin{tabular}{|c|c|c|c|c|c|c|c|}
\hline $\begin{array}{c}\text { Program } \\
\text { Title } \\
\end{array}$ & $\begin{array}{c}\text { Date } \\
\text { Launched }\end{array}$ & Scope & $\begin{array}{l}\text { Type of } \\
\text { Operator }\end{array}$ & $\begin{array}{c}\text { No. of } \\
\text { Operators } \\
\end{array}$ & \multicolumn{2}{|c|}{ Legislation } & Further Plans (Deadlines) \\
\hline \multicolumn{6}{|c|}{ Accreditation (Components, process) } & & Benefits \\
\hline \multicolumn{6}{|c|}{ 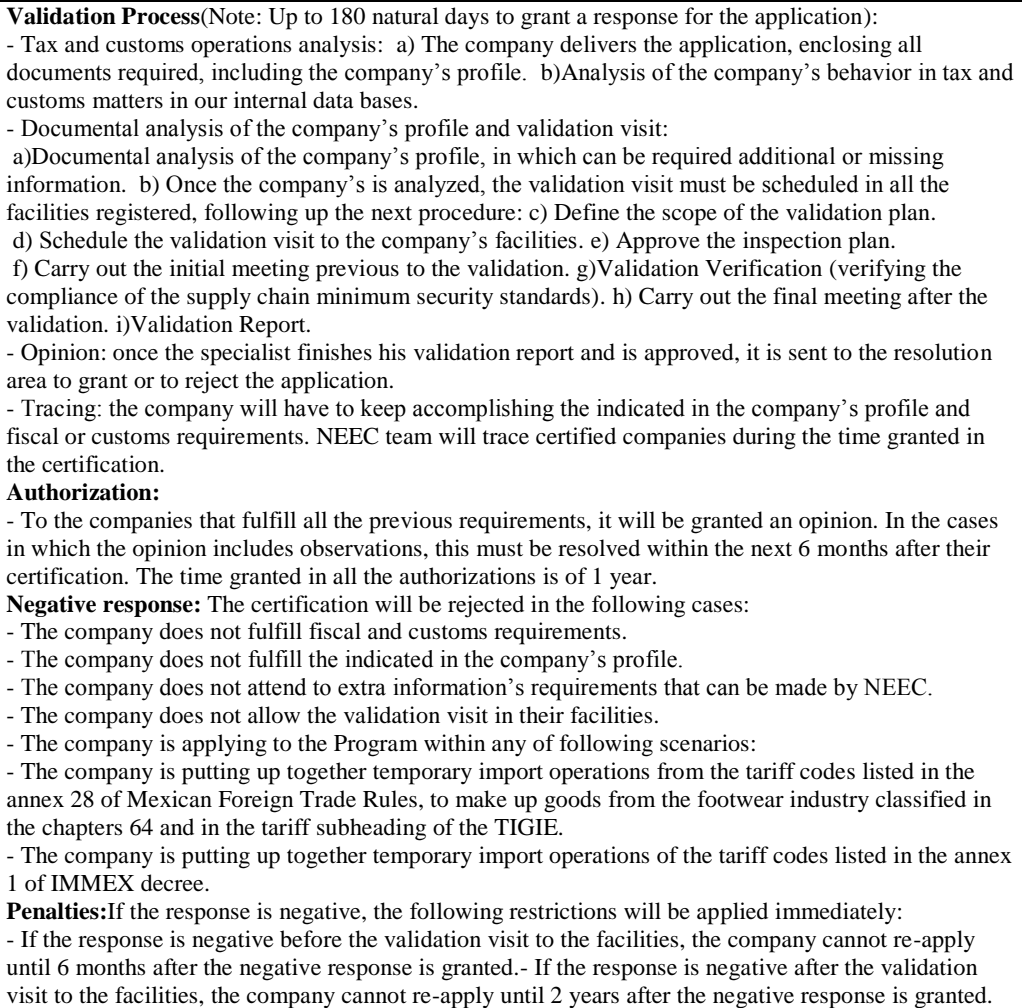 } & \multicolumn{2}{|c|}{$\begin{array}{l}\text { NEEC companies have more than } 30 \\
\text { logistics-customs benefits. The most } \\
\text { representative benefits are: } \\
\text { - Reduction of the risk level associated to } \\
\text { its foreign trade operation. } \\
\text { - Less inspections and priority for physical } \\
\text { as well as documental inspections - speed } \\
\text { up in trade operations. } \\
\text { - Express lane. } \\
\text { - Assignment of a specialist person and a } \\
\text { NEEC advisor. }\end{array}$} \\
\hline
\end{tabular}

Source: WCO AEO Compendium 2016.

\footnotetext{
${ }^{25} \mathrm{http}: / / \mathrm{www}$. sunat.gob.pe/orientacionaduanera/oea/empresasCertificadas.html\# (visited in March, 2017).

${ }^{26}$ On this subject, see e.g. the Business Journal 'Gestión': http://gestion.pe/empresas/sunat-acredito-diezempresas-como-operadores-economicos-autorizados-2086434 (visited in March, 2017).

${ }^{27}$ Source: http://gestion.pe/economia/operadores-economicos-autorizados-agilizaron-exportaciones-masus-1536-millones-2183410 (visited in March, 2017).
} 
In the context of the PA, Mexico has the biggest AEO Program, known as NEEC. It is relevant to mention that data from the Mexican Customs Authority (SAT) differs from that of WCO, as the former counts 516 certified AEO's, with a quick progression from 2012 to 2017.

These numbers are no surprise, given the fact that Mexico is the closest economy to the USA, and also considering the FTA between them. Thus, it is an imperative for them to certify their companies -e.g., if a company in Mexico has AEO status, its delivery times are reduced from 4 hours to 24 minutes, in order to cross the border. This is the difference between delivering goods in the morning of the same day, versus doing it in the following business day; a significant competitive advantage. ${ }^{28}$ Also, the AEO Program has a proven expansive effect, in which certified companies are encouraged to have their whole trade chains become certified as well, in order to continue to do business with them. Additionally, there is a C-TPAT peculiarity that takes place, in which certified AEO's sometimes involve visits to their partners in other countries -in this case, Mexico-, so that the whole chain can be considered safe.

Other benefits specific to the NEEC Program are: fewer revision rates, waiver of guarantees, and summary declarations presented once a month. All of these have a concrete monetary impact, reducing paperwork and man hours. There is another very relevant development in analyzing Mexico, as they have already signed a MRA with the USA, on October 2014. Undoubtedly this puts them on the lead in relation to the PA, positioning them as the example to follow for the remaining members.

\section{Common Obstacles Faced by AEO Programs in the PA.}

As we have seen, with the sole exception of Mexico, PA AEO Programs remain small in their scope and reach, but are functioning in an articulate manner, hoping to be structured as a multilateral effort in the near future. Many of the setbacks encountered in this investigation involve resistance to new institutions, consolidation of the benefits offered to certified companies, and paradigm changes that need to take place among both the private and public sectors.

A standout example of these problems has been that of Chile, where only recently the law that creates AEOs has been passed. Although pilot programs have been put in place, there is a lot of catching up to do, especially keeping in mind that the PA MRA is expected to be in place by 2018 , a mere one-year time frame.

Analysis in this particular topic will be very abridged, since other points will be covered subsequently in the prognosis.

\footnotetext{
${ }^{28}$ This example was given to us by Jorge Yany, as a direct experience shared with him within the PA's Technical Group.
} 


\section{Conclusions: PA's AEO Programs Prognosis, Based on the C-TPAT Model.}

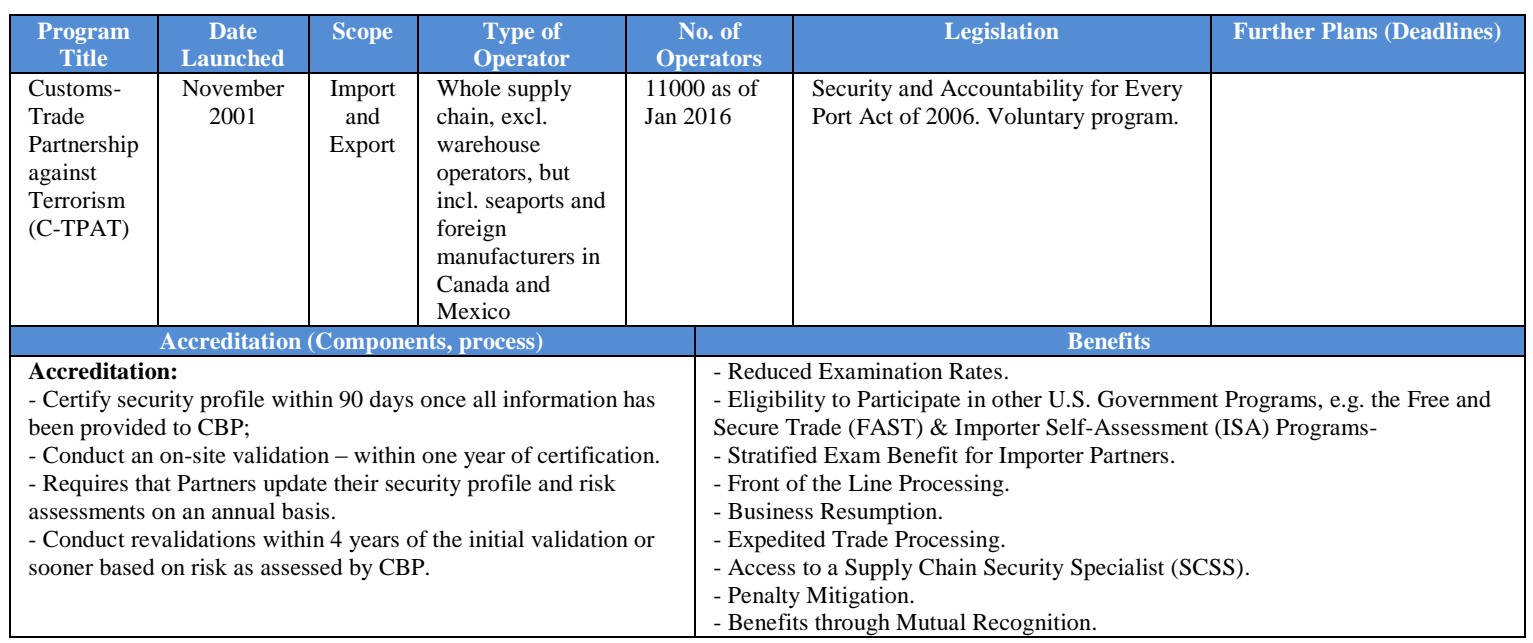

Source: WCO AEO Compendium 2016.

\section{Container Port Traffic (in TEUs): AP vs United States. ${ }^{29}$}
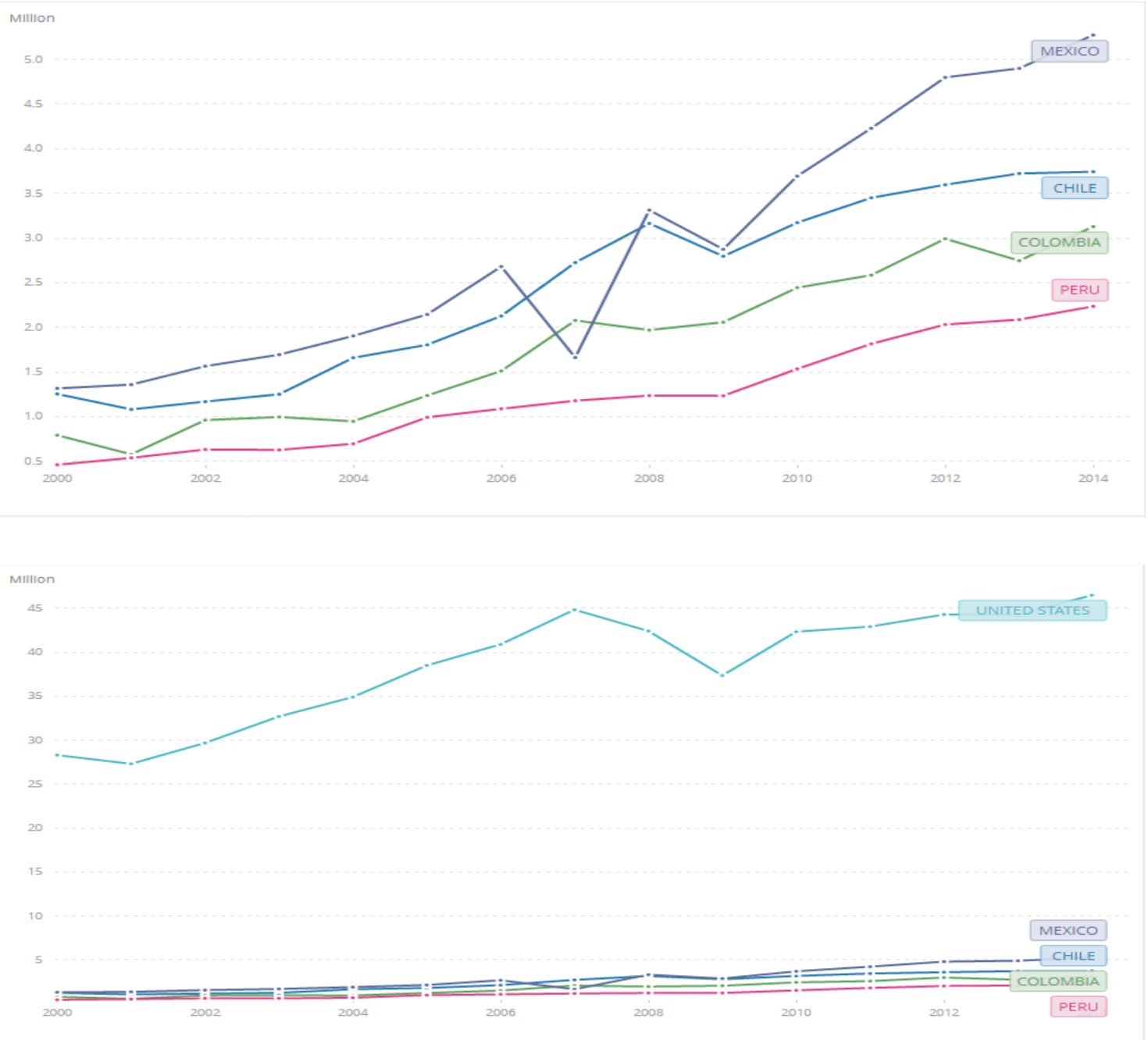

Source: World Bank Data Website.

${ }^{29}$ Source: http://data.worldbank.org (visited in March, 2017).

TEU: Twenty-foot Equivalent Unit. 
When analyzing international phenomena, the magnitudes and impact that each individual country has on a global scale should be kept in mind. Considering this, the abysmal breach that separates most Latin American countries and the USA -best represented above in the graphic of their port traffic - in painfully obvious; however, this paper looks to project the future success of AEO programs in the PA, based on the North American model. Thus, while acknowledging this large difference, each PA member must be analyzed within their own particular reality.

As already shown, Mexico has the biggest AEO Program in the PA, maintaining a considerable difference with Peru -tenfold-, followed by Colombia with half as many AEO's as Peru. But even if the PA is considered as a whole, with 588 certified AEOs, it still only represents 5,19\% of C-TPAT's (with 11325 certified AEO's). If forced to pinpoint the most relevant reasons behind this, it would definitely be the importance of the unity behind a paradigm: the USA held a standpoint that allowed them to set firm bases for their program, especially regarding regulations, while projecting those principles to the international trade system. This way, the innovations were enforced by the CBP and accepted as a standard by the community.

Certainly the long list of palpable C-TPAT benefits that have already been covered, were a sufficient incentive for every link in the chain to become interested in investing to be incorporated in the Program. This is the main obstacle PA countries have to overcome: creating real benefits that are attractive enough for operators to start thinking about certification. Mexico is pointing towards the right direction in this matter, offering benefits that translate into actual savings.

Another very important setback in the PA is the dissimilar level of development of the Programs, where an equivalent stage must be reached soon in order for them to flourish. This is not a matter of numbers, but of the quality of the regulation and what it offers to those interested in participating. It is certain that once this happens and the MRA is concluded, the PA will be en route to multilateral progression. To provide evidence of this affirmation, one should consider that, when an operator is presented with the opportunity to be certified in 4 economies at once, AEO status will be a much more coveted one.

As the PA's efforts also aim at establishing more fruitful economic relations within the block, the impact that these multilateral programs could have on strengthening the exchange, are noticeable. More importantly, after withdrawal of the USA from the TPP, reunions within the PA are focused on building alliances throughout the Pacific, and specifically with the Asia - Pacific Region. Heraldo Muñoz, Chile's Foreign Relations Minister, said a few weeks ago that the Alliance will initiate talks with partners in the Asia Pacific to achieve free trade agreements with high-quality 
standards and short deadlines. ${ }^{30}$ These FTAs could present new opportunities to create AEO networks, and will very likely be a stimulus for more certifications.

Finally, it is necessary to state that, since each PA country has its own peculiarities, it is difficult to foresee a similar outcome as that of C-TPAT. If the process discussed in this paper is to happen in the long term, it will be within a muchnecessary multilateral framework. As the PA Mutual Recognition Agreement is expected for 2018, and if it comes to fruition -as the very first multilateral MRA-, a very solid and steady rise in the numbers of certified AEOs can be expected. But as of this moment, it is still a time of consolidation and setting the foundations for that somewhat distant expectation.

\section{Bibliographic References and Websites.}

Additional Protocol to the Pacific Alliance's Framework Agreement.

BBC News Site in Spanish http://www.bbc.com/mundo/noticias-36709925 (visited in March, 2017).

Chilean Customs Service Official Website, https://www.aduana.cl (Visited in April, 2017):

- AEO World Programs https://www.aduana.cl/programas-oea-en-elmundo/aduana/2013-11-28/135114.html

- PA's Action Plan for MRA https://www.aduana.cl/alianza-del-pacificounificara-criterios-de-sus-programas-oea/aduana/2016-05-12/164516.html

C-TPAT: Customs-Trade Partnership Against Terrorism - U.S. Customs and Borders Protection (Visited in March, 2017): https://www.cbp.gov/border-security/portsentry/cargo-security/c-tpat-customs-trade-partnership-against-terrorism

http://c-tpat.com/what-is-ctpat/

ECLAC Official Website (Visited in April, 2017)

http://www.cepal.org/sites/default/files/infographic/files/cepal_ranking_puertos_espokweb.pdf

Facilitación del comercio: reducción de las ineficiencias en frontera (Trade Facilitation: Reduction of Border Inefficiencies), December 2013, WTO Ministerial Conference, ICTSD Revista Puentes (Bridges Magazine), Volume 14 - Number 10: http://www.ictsd.org/bridges-news/puentes/news/facilitaci\%C3\%B3n-del-comercioreducci\%C3\%B3n-de-las-ineficiencias-en-frontera

\footnotetext{
${ }^{30}$ Muñoz, Heraldo, on his Blog in the Chilean Newspaper 'La Tercera', http://www.latercera.com/voces/voluntad-de-integracion/ visited in March, 2017.
} 
Gestión Business Journal http://gestion.pe/empresas/sunat-acredito-diez-empresascomo-operadores-economicos-autorizados-2086434 (visited in March, 2017).

http://gestion.pe/economia/operadores-economicos-autorizados-agilizaronexportaciones-mas-us-1536-millones-2183410 (visited in March, 2017).

Inter American Development Bank Official Website

http://www.iadb.org/en/topics/trade/customs-of-the-pacific-alliance-

countries,20247.html (Visited in March, 2017)

Interview via Email, answers received in January 6, 2017, from Luz Murcia Reyes, AEO Coordinator for Colombia's DIAN.

Interview with Jorge Yany, Chile's AEO Program Director, held at the National Direction of the Chilean Customs Service, in Valparaíso, on October 2016.

Mexicos's SAT Official Website http://www.sat.gob.mx (visited in March, 2017).

MIQ Logistics Website http://www.miq.com (visited in April, 2017).

Oliger, Gerard, Operador Económico Autorizado: Una Herramienta para Mejorar la Competitividad de las Empresas y Aumentar la Seguridad de Nuestras Fronteras, Trabajo Final de Graduación, Magíster RR.II. PUCV, 2016.(Authorized Economic Operator: A Tool to Improve the Competitiveness of Companies and Increase the Security of Our Borders, Graduation Final Work, International Relations Magister PUCV, 2016).

Oviedo Umaña, Roberto Alonso - Chile y la Experiencia Internacional en el Programa del Operador Económico Autorizado (OEA) (Chile and the International Experience with the AEO Program), March 2013, University of Chile.

Pacific Alliance Official Website: https://alianzapacificonet/en/ (Visited in April, 2017).

Peru's SUNAT Official Website http://www.sunat.gob.pe (Visited in March, 2017).

Polner, Mariya - Compendium of Authorized Economic Operator (AEO) Programs (July 2010), WCO.

Trade Facilitation Implementation Guide (UN): http://tfig.unece.org/index.html (visited in December, 2016).

The Authorized Economic Operator and the Small and Medium Enterprise FAQ (May 2010) - World Customs Organization. 
United States Customs and Border Protection, Official Website http://www.cbp.gov (visited in January, 2017).

World Bank Official Websitehttp://data.worldbank.org (visited in March, 2017).

WCO AEO Compendium 2016, available on http://www.wcoomd.org (visited in February, 2017).

WCO Annual Report 2015-2016, available at http://www.wcoomd.org (visited in February, 2017).

WCO SAFE Framework of Standards to Secure and Facilitate Global Trade, June 2015, available on http://www.wcoomd.org(visited in February, 2017).

World Shipping Website http://www.worldshipping.org/about-the-industry/globaltrade/top-50-world-container-ports (visited in March)

World Trade Organization - Trade Facilitation Website:

https://www.wto.org/english/tratop_e/tradfa_e/tradfa_e.htm (visited in December, 2016). 